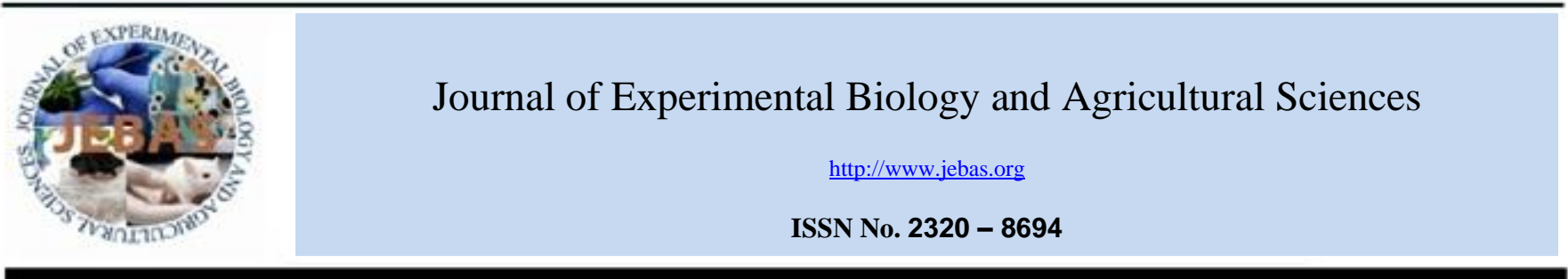

\title{
Effect of probiotic Bacillus spp.-supplemented feed on the growth, length-weight relationship, and condition factor of Nile tilapia (Oreochromis niloticus)
}

\author{
Jaypee S. Samson ${ }^{1,2 *}$ (i) \\ ${ }^{1}$ College of Fisheries, Central Luzon State University, Science City of Muñoz 3120, Nueva Ecija, Philippines \\ ${ }^{2}$ Freshwater Aquaculture Center, Central Luzon State University, Science City of Muñoz 3120, Nueva Ecija, Philippines \\ Received - November 29, 2021; Revision - February 02, 2022; Accepted - February 20, 2022 \\ Available Online - February 28, 2022 \\ DOI: http://dx.doi.org/10.18006/2022.10(1).90.96
}

KEYWORDS
Feed conversion ratio
Aquaculture
Nile tilapia
Bacillus
Probiotics
Feeding

\begin{abstract}
This study was carried out to evaluate the effect of two probiotic Bacillus spp. (RM10 and BFAR9) on the growth, length-weight relationship (LWR), and condition factor (k) of Nile tilapia (Oreochromis niloticus). For this, one hundred thirty-five fingerlings ( $1.12 \pm 0.08 \mathrm{~g}$ weight and $1.26 \pm 0.15 \mathrm{~cm}$ length) were divided into three groups (Control, RM10, and BFAR9) and distributed into nine circular concrete tanks. The fish were fed with commercial (control) and Bacillus spp. supplemented diets at 5\% of body weight for 56 days. The results of the study revealed better $(P<0.05)$ growth concerning average body weight (ABW - 17.12 $\pm 0.71 \mathrm{~g}$ ), specific growth rate (SGR - 4.89 $\pm 0.22 \mathrm{~g} \cdot \mathrm{day}^{-1}$ ), absolute growth (AG $16.02 \pm 0.78 \mathrm{~g}$ ), and feed conversion ratio (FCR - 1.31 \pm 0.09 ) in the group fed with Bacillus sp. RM10 as compared to the control (ABW- 13.25 $\pm 2.34 \mathrm{~g}$; SGR - 4.41 $\pm 0.17 \mathrm{~g} \cdot \mathrm{day}^{-1}$; AG - 12.13 $\pm 2.25 \mathrm{~g}$; FCR $1.62 \pm 0.11)$. The LWR in all experimental treatments showed a significant correlation $(P<0.05)$ with an $\mathrm{R}^{2}$ value of $0.988,0.966$, and 0.979 for Control, RM10, and BFAR9, respectively. The $\mathrm{k}$ value revealed that all treatments are in good condition as $\mathrm{k}$ value is greater than 1 (1.913, 2.038, and 1.896 for control, RM10, and BFAR9 respectively). The result of the current study revealed that application of Bacillus sp. RM10 improves the growth and feed utilization in Nile tilapia.
\end{abstract}

* Corresponding author

E-mail: samsonjaypee@clsu.edu.ph

Peer review under responsibility of Journal of Experimental Biology and Agricultural Sciences.

Production and Hosting by Horizon Publisher India [HPI] (http://www.horizonpublisherindia.in/).

All rights reserved.
All the articles published by Journal of Experimental Biology and Agricultural Sciences are licensed under a Creative Commons Attribution-NonCommercial 4.0 International License Based on a work at www.jebas.org.

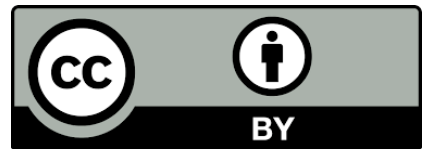




\section{Introduction}

Aquaculture is playing an important role in increasing fish production and helping to meet the growing demand of the global population for fishery products. One of the most popular aquaculture species are the tilapias (Oreochromis spp.), which is the worldwide second most farmed fish (Prabu et al. 2019). These species are native to Africa and the Middle East and were introduced into over 90 countries for aquaculture and fisheries (Watanabe et al. 2002; Prabu et al. 2019). The global production of tilapia in 2015 was estimated at 5,576,800 MT (Prabu et al., 2019). In the Philippines, tilapia is the second most farmed fish with an estimated production of 277,006 MT in 2018, which contributes to $12.02 \%$ of the total aquaculture production of the country (Bureau of Fisheries and Aquatic Resources 2018). Tilapia production has quadrupled over the past decade and continued to increase global production rapidly due to its suitability for aquaculture, stable market prices, and the increasing demand for food fish as a result of the growing population (Prabu et al. 2019). However, this intensification led to the proliferation of antibiotic-resistant microorganisms as a result of the improper use of chemotherapeutic agents to improve the growth and disease resistance of the fish. As an alternative, recent studies explored the use of beneficial bacteria or probiotics to encourage more ecofriendly aquaculture (Balcazar et al. 2006). Bacillus spp. are widely used as a probiotic microorganism for aquatic animals to promote growth performances, disease resistance, and better immune response (Balcazar et al., 2006). These bacteria are suitable probiotic candidates since they are generally nonpathogenic and non-toxic when fed to fish, can survive under harsh environmental conditions, and produce antimicrobial substances as compared to other probiotics (Kuebutornye et al. 2019).

The need for sustainable aquaculture has encouraged exploration into the use of probiotics on aquatic organisms. The original interest was focused on their use as a growth promoter and to improve the health of animals; however, new extents have been found, such as their effect on reproduction or stress tolerance, although this requires a more scientific development (Cruz et al. 2012). The information on probiotics has increased in the past years and currently, it has been established that they have an antimicrobial effect on their host organism (Cruz et al. 2012). Probiotic bacteria enact their antimicrobial effect by amending the intestinal microbiota of their host through secretion of antibacterial substances (bacteriocins and organic acids), prevention of pathogen adhesion to the intestine, competing for nutrients essential for pathogen survival, and production of antitoxin effect (Cruz et al. 2012). Furthermore, probiotics are also capable of modifying the immune system, regulating the allergic response of the body, and reducing the proliferation of cancer in mammals. As a result, when probiotics are provided in a certain concentration these are positively affecting the host's health (Myers 2007).
Previous studies also reported a significant effect of Bacillus spp. on growth, disease resistance, and hematological parameters of Nile tilapia (Soltan et al. 2016; Sutthi et al. 2018; Elsabagh et al. 2018; Kuebutornye et al. 2020; Won et al. 2020; Ghalwash et al. 2021) and other aquatic species (Hauville et al. 2016; Munir et al. 2016; da Paixão et al. 2017; Kong et al. 2017; Wang et al. 2017; Amoah et al. 2021; Saravanan et al. 2021). In this present study, the effect of two previously isolated Bacillus spp. on the growth performance, length-weight relationship, and condition factor of Nile tilapia was evaluated.

\section{Materials and Methods}

\subsection{Preparation of Bacteria and Experimental Diets}

Two probiotic strains viz., BFAR9 and RM10 of Bacillus spp. with GenBank accession numbers: MH919302 and MH919308, isolated from African nightcrawler earthworm (Eudrilus eugeniae) were used in this study (Samson et al., 2020). Overnight cultures of the probiotic strains were suspended in a $250 \mathrm{~mL}$ nutrient broth and incubated at $37{ }^{\circ} \mathrm{C}$ for 24 hours. The suspensions were aseptically transferred into sterile test tubes, pelleted, washed, and suspended in Phosphate-buffered Solution (PBS). The bacterial density was adjusted using the McFarland standard. Dilutions were carried out using PBS to have a similar bacterial density (McFarland, 1907).

Experimental diets were prepared using a commercial feed $(31 \%$ crude protein, $5 \%$ lipid, $8 \%$ crude fiber, and $12 \%$ crude ash) as the basal diet (control). The probiotic-treated diets were prepared to contain a single strain of Bacillus spp. at $10^{8} \mathrm{CFU} \cdot \mathrm{g}^{-1}$ of feed. The selected isolates were sprayed on the basal diet and air-dried for 2 hours before storing at $4^{\circ} \mathrm{C}$.

\subsection{Experimental Fish and Set-up}

One hundred thirty-five $O$. niloticus fingerlings (FaST strain) were obtained from the Freshwater Aquaculture Center, Central Luzon State University, Science City of Muñoz, Nueva Ecija, Philippines. Experimental fish were allowed to acclimatize for 7 days before the experiment. The fingerlings were randomly distributed into 9 circular concrete tanks (200-L capacity) and divided into 3 experimental groups (three replicates per group). Each group consists of 45 fish, which had an initial weight and length of $1.12 \pm 0.08 \mathrm{~g}$ and $1.26 \pm 0.15 \mathrm{~cm}$, respectively. Prepared diets were given thrice daily (8:00, 12:00, and 16:00), initially at $5 \%$ of fish body weight per day for 56 days. Sampling was done biweekly to measure the length and weight of the fish and adjust the feeding ration. The water quality parameters such as temperature, dissolved oxygen, and $\mathrm{pH}$ were measured daily using the YSI multiparameter (YSI 556 - YSI Incorporation, Yellow Spring, USA) 


\subsection{Data Collection}

At the end of the feeding trial, all fish were measured and weighed. The specific growth rate (SGR), absolute growth (AG), feed conversion ratio (FCR), survival rate (SR) and condition factor $(\mathrm{k})$ were measured as follows (Bagenal 1978; Fulton1904):

$$
\begin{gathered}
\mathrm{SGR}=\frac{(\ln [\text { final weight }]-\ln [\text { initial weight }])}{(\text { time interval in days })} \times 100 \\
\mathrm{AG}=\text { Final weight }(\mathrm{g})-\text { Initial weight }(\mathrm{g}) \\
\mathrm{FCR}=\frac{\text { Amount of feed given }(\mathrm{g})}{\text { Weight gain }(\mathrm{g})} \\
\mathrm{SR}(\%)=\frac{\text { No. of individuals at the end of the experiment }}{\text { No of individuals at the beginning of the study }} \times 100 \\
\mathrm{k}=100 \times \frac{\text { Weight }(\mathrm{g})}{\text { Length }(\mathrm{cm})^{3}}
\end{gathered}
$$

\subsection{Length-weight relationship}

The length and weight of fish were tabulated and analyzed after 56 days. The relationship between the length $(\mathrm{L}, \mathrm{cm})$ and weight $(\mathrm{W}$, g) was calculated by regression equation (Keys 1928)

$$
\mathrm{W}=\alpha \times \mathrm{L}^{\mathrm{b}}
$$

Here $\alpha$ represents the antilog of the intercept of the regression curve, and $b$ is the regression coefficient. The degree of association between $\mathrm{L}$ and $\mathrm{W}$ was calculated by the correlation coefficient (r). In the length-weigh relationship, the value of exponent $\mathrm{b}$ provides information on fish growth; when $b=3$, the increase in weight is isometric, while $\mathrm{b}>3$ means increase of weight is positive allometric, and if $\mathrm{b}<3$, the increase of weight is negative allometric (Tesch 1968)

\subsection{Statistical Analyses}

Results were analyzed by one-way analysis of variance (ANOVA), followed by Duncan's Multiple Range Test (DMRT) at a significant level of $P<0.05$ using R Statistics software. Results are presented as means \pm SD. The LWR was calculated using linear regression analysis in Microsoft Excel using the log-transformed data of weight and length.

\section{Results}

\subsection{Growth Performance and Survival}

The data on growth performance, survival, and condition factor of experimental fish are presented in Table 1. Results of the study revealed that the initial length and weight measurements of the fish had no significant difference among the groups. Further, no significant differences between the two probiotic-fed groups in terms of length and weight; however, significantly higher $(P<0.05)$ ABW (17.12 g), SGR (4.89 g. day $\left.{ }^{-1}\right)$, and AG (16.02 g) was observed from Bacillus sp. RM10-fed group compared to the control group $\left(\mathrm{ABW}=13.25 \mathrm{~g}, \quad \mathrm{SGR}=4.41 \mathrm{~g} \cdot \mathrm{day}^{-1}\right.$ and $\mathrm{AG}=$ $12.13 \mathrm{~g}$ ). On the other hand, no significant difference was observed in the length of the fish among all treatments. Furthermore, in terms of feed efficiency, the results of the current study showed significantly lower FCR in RM10 (1.31) compared to the control (1.62). The survival rate of the experimental fish also revealed that

\begin{tabular}{|c|c|c|c|}
\hline \multirow{2}{*}{ PARAMETERS } & \multicolumn{3}{|c|}{ TREATMENT } \\
\hline & Control & RM10 & BFAR9 \\
\hline Initial Body Length (IBL) $(\mathrm{cm})$ & $3.89 \pm 0.44^{\mathrm{a}}$ & $3.91 \pm 0.19^{\mathrm{a}}$ & $3.82 \pm 0.19^{\mathrm{a}}$ \\
\hline Initial Body Weight (IBW) (g) & $1.11 \pm 0.10^{\mathrm{a}}$ & $1.11 \pm 0.11^{\mathrm{a}}$ & $1.14 \pm 0.09^{\mathrm{a}}$ \\
\hline Final Body Length (FBL) $(\mathrm{cm})$ & $8.83 \pm 0.53^{\mathrm{a}}$ & $9.44 \pm 0.24^{\mathrm{a}}$ & $9.18 \pm 0.16^{\mathrm{a}}$ \\
\hline Final Body Weight (FBW) (g) & $13.25 \pm 2.34^{\mathrm{b}}$ & $17.12 \pm 0.71^{\mathrm{a}}$ & $16.02 \pm 0.28^{\mathrm{ab}}$ \\
\hline Feed Conversion Ratio (FCR) & $1.62 \pm 0.11^{\mathrm{a}}$ & $1.31 \pm 0.09^{\mathrm{b}}$ & $1.54 \pm 0.15^{\mathrm{ab}}$ \\
\hline Specific Growth Rate (SGR) $\left(\mathrm{g} \mathrm{day}^{-1}\right)$ & $4.41 \pm 0.17^{\mathrm{b}}$ & $4.89 \pm 0.22^{\mathrm{a}}$ & $4.71 \pm 0.11^{\mathrm{ab}}$ \\
\hline Absolute Growth (AG) (g) & $12.13 \pm 2.25^{\mathrm{b}}$ & $16.02 \pm 0.78^{\mathrm{a}}$ & $14.85 \pm 0.20^{\mathrm{ab}}$ \\
\hline Survival Rate (SR) (\%) & $83.33 \pm 15.28^{\mathrm{a}}$ & $80.00 \pm 10.00^{\mathrm{a}}$ & $90.00 \pm 17.32^{\mathrm{a}}$ \\
\hline Condition Factor $(\mathrm{k})$ & $1.91 \pm 0.02^{\mathrm{a}}$ & $2.04 \pm 0.11^{\mathrm{a}}$ & $1.90 \pm 0.08^{\mathrm{a}}$ \\
\hline
\end{tabular}
there are no significant differences in all treatments. After 56 days of culture, all treatments have $\geq 80 \%$ survival. The water quality parameters recorded during the experiment are temperature $26.7 \pm$ $0.8^{\circ} \mathrm{C}, \mathrm{pH} 7.8 \pm 0.2$, and dissolved oxygen level $4.65 \pm 1.16 \mathrm{ppm}$.

Table 1 Growth performance, feed utilization, survival, and condition factor of Nile tilapia fed with probiotic Bacillus spp.

Data are given as mean $\pm \mathrm{SD}(\mathrm{n}=3)$. The mean values in the same row with different superscript letters are significantly different at $P<0.05$.

Journal of Experimental Biology and Agricultural Sciences http://www.jebas.org 

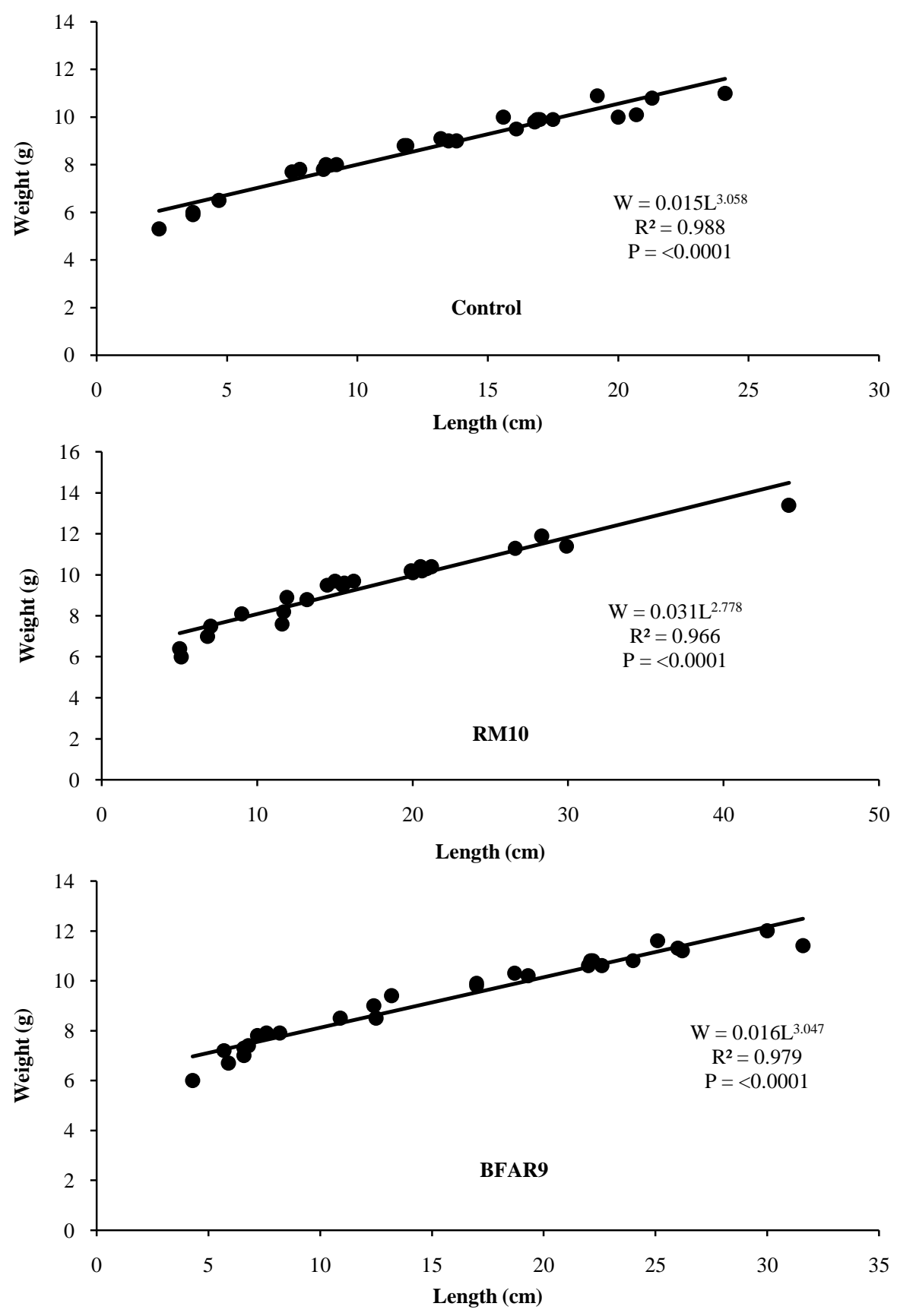

Figure 1 Logarithmic regression of weight and length data of Nile tilapia fed with probiotic Bacillus spp.

\subsection{Length-weight Relationship and Condition Factor}

The length-weight relationship of the non-probiotic-fed and probiotic-fed groups was evaluated after the feeding trial. The logarithmic regression of LWR and coefficient of determination values $\left(\mathrm{R}^{2}\right)$ are presented in Figure 1. Results showed a significant correlation $(P<0.05)$ between the length and the weight among all experimental groups with an $\mathrm{R}^{2}$ value of $0.988,0.966$, and 0.979 for Control, RM10, and BFAR9, respectively. Moreover, the value of slope (b) in BFAR9 (3.047) and Control (3.058) is close to 3, except for RM10 (2.778). No significant differences were reported in the condition factor on all treatment groups. However, the condition factor revealed that the experimental fish in all groups are in good condition as demonstrated by the $\mathrm{k}$-value. All groups that have $\mathrm{k}$-value is greater than 1 considered as good one (Control $=1.913, \mathrm{RM} 10=2.038$, and BFAR9 $=1.896$ ). 


\section{Discussion and Conclusions}

The applications of probiotics in aquaculture have already been reported for several years. The increasing demand for an ecofriendlier approach in combating the emerging diseases in aquaculture and intensifying of production has turned the industry to explore the use of these microorganisms. Probiotic application has already been proven to increase aquaculture production by improving the growth and survival of the cultured species. In the present study, the application of the probiotic Bacillus spp. improved the growth performance of the fish. Higher ABW and growth parameters (AG and SGR) were observed in the experimental group fed with Bacillus spp. RM10. Previous research studies have already reported the beneficial effect of Bacillus probiotics application on fish growth. Similar findings were reported in Nile tilapia (Apún-Molina et al. 2009; Zhou et al. 2009; Ridha and Azad 2012; Soltan et al. 2016; Sutthi et al. 2018; Opiyo et al. 2019; Rahman 2019;), white shrimp, (Litopenaeus vannamei) (Nimrat et al. 2012; Zokaeifar et al. 2012), rainbow trout (Oncorhynchus mykiss), and African catfish (Clarias gariepinus). Previous studies showed the colonization ability of Bacillus spp. in the gut of the fish. This ability aids in imposing the beneficial effects of probiotic bacteria through stimulation and production of digestive enzymes, enhanced organic acid production, reducing the antinutritional factors of feed ingredients, and collectively maintaining a healthy gut; thus, improving the digestion and nutrient absorption of the host. This is demonstrated by the lower FCR value of the group fed with Bacillus sp. RM10, which showed that the probiotic application improved the feed utilization of the fish. On the other hand, the application of Bacillus sp. BFAR9 did not result in any significant improvement on Nile tilapia growth. Similar findings were observed in, tambaqui (Colossoma macropomum) (da Paixão et al. 2017), gilthead sea bream (Sparus aurata) (Arı̆̆ et al. 2013), and Nile tilapia (Shelby et al. 2006; Silva et al. 2015). Although growth improvement is not evident in these reports, a significant increase in the villi height of the intestine (Silva et al. 2015) and digestive enzyme activities (Arığ et al. 2013) revealed that the application of Bacillus probiotics have a positive effect on the digestion of the fish. Therefore, the effect of probiotic bacteria can be possibly observed in other aspects of the host, such as enhanced immunity, digestion, pathogen prevention, stress tolerance, and reproduction. Furthermore, it is also possible that the effect of a certain strain of probiotics varies in every species of fish. Similarly, the probiotic effect of Bacillus spp. might be due to differences in each strain or species of bacteria.

In the present study, the effect of Bacillus probiotics application in the LWR and condition factor of Nile tilapia was evaluated. The results showed a significant correlation between the length and weight of the fish. In the LWR, the value of slope (b) provides information on fish growth, $\mathrm{b}<3$ is said to be negative allometric, $\mathrm{b}=3$ is isometric and $\mathrm{b}>3$ is positive allometric. Isometric growth pattern (i.e., the proportional increase in length and weight that gives fish ideal shapes) was observed in BFAR9 (3.047) and control (3.058) as indicated by their slope value, which is close to the value of ideal growth $(b=3)$, as suggested by Froese (2006). Although experimental groups fed with Bacillus spp. RM10 demonstrated a lower slope value (2.778) than the ideal growth value, it is still within the acceptable range of 2.5-3.5 which was estimated by Froese (2006). Furthermore, the condition factor in all treatments showed that the experimental fish are in good condition $(\mathrm{k} \geq 1)$. This condition factor is widely used in fisheries and general fish biology studies. It is calculated from the relationship between the weight of a fish and its length, to describe the condition of that individual. Previous studies have utilized this parameter to evaluate the overall condition of aquatic organisms as affected by several factors and for fish stock assessment purposes. The present study demonstrated the beneficial effect of the probiotic Bacillus spp. application in the growth of Nile tilapia. Further intensive investigations are required to evaluate the role of these microorganisms in disease resistance, stress tolerance, and fish reproduction.

In conclusion, this study revealed that supplementation of Bacillus sp. RM10 in the diet of Nile tilapia improves the growth performance and feed utilization of the fish. Therefore, based on the result of this study, the application of Bacillus sp. RM10 in the diet can increase the production and lessen the feed requirements of Nile tilapia.

\section{Abbreviations}

Average Body Weight (ABW), Specific Growth Rate (SGR), Absolute Growth (AG), Survival Rate (SR) and Feed Conversion Ratio (FCR)

\section{Acknowledgment}

The author would like to acknowledge the assistance of the College of Fisheries and Freshwater Aquaculture Center, Central Luzon State University where the study was conducted.

\section{Conflict of Interest}

The author declares no conflict of interest.

\section{References}

Amoah, K., Dong, X., Tan, B., Zhang, S., et al. (2021). Effects of three probiotic strains (Bacillus coagulans, B. licheniformis and Paenibacillus polymyxa) on growth, immune response, gut morphology and microbiota, and resistance against Vibrio harveyi of northern whitings, Sillago sihama Forsskál (1775). Animal Feed 
Science and Technology, 277, 114958. https://doi.org/10.1016/ j.anifeedsci.2021.114958

Apún-Molina, J. P., Santamaría- Miranda, A., Luna-González, A., Martínez-Díaz, S. F., \& Rojas-Contreras, M. (2009). Effect of potential probiotic bacteria on growth and survival of tilapia Oreochromis niloticus L., cultured in the laboratory under high density and suboptimum temperature. Aquaculture Research, 40(8), 887-894. https://doi.org/10.1111/j.1365-2109.2009.02172.x

Arığ, N., Suzer, C., Gökvardar, A., Başaran, F., et al. (2013). Effects of probiotic (Bacillus sp.) supplementation during larval development of gilthead sea bream (Sparus aurata, L.). Turkish Journal of Fisheries and Aquatic Sciences, 13, 407-414. https://doi.org/DOI: 10.4194/1303-2712-v13_3_03

Bagenal, T. (1978). Methods for assessment of fish production in fresh waters (3rd ed.). Oxford (UK) Blackwell Scientific Publication.

Balcazar, J., Blas, I., Ruizzarzuela, I., Cunningham, D., Vendrell, D., \&Muzquiz, J. (2006). The role of probiotics in aquaculture. Veterinary Microbiology, 114(3-4), 173-186. https://doi.org/10.1016/j.vetmic.2006.01.009

Bureau of Fisheries and Aquatic Resources. (2018). Philippine Fisheries Profile. https://www.bfar.da.gov.ph/publication.jsp?id= 2369\#post

Cruz, P. M., Ibáñez, A. L., Monroy Hermosillo, O. A., \& Ramírez Saad, H. C. (2012). Use of probiotics in aquaculture. ISRN Microbiology, 2012, 1-13. https://doi.org/10.5402/2012/916845

da Paixão, A. E. M., dos Santos, J. C., Pinto, M. S., Pereira, D. S. P., et al. (2017). Effect of commercial probiotics (Bacillus subtilis and Saccharomyces cerevisiae) on growth performance, body composition, hematology parameters, and disease resistance against Streptococcus agalactiae in tambaqui (Colossoma macropoтum). Aquaculture International, 25(6), 2035-2045. https://doi.org/10.1007/s10499-017-0173-7

Elsabagh, M., Mohamed, R., Moustafa, E. M., Hamza, A., et al. (2018). Assessing the impact of Bacillus strains mixture probiotic on water quality, growth performance, blood profile and intestinal morphology of Nile tilapia, Oreochromis niloticus. Aquaculture Nutrition, 24(6), 1613-1622. https://doi.org/10.1111/anu.12797

Froese, R. (2006). Cube law, condition factor and weight-length relationships: History, meta-analysis and recommendations. Journal of Applied Ichthyology, 22(4), 241-253. https://doi.org/10.1111/j.1439-0426.2006.00805.x
Fulton, T. W. (1904). The Rate of Growth of Fishes. [Twentysecond Annual Report, Part III] (pp. 141-241). Fisheries Board of Scotland, Edinburgh.

Ghalwash, H. R., Salah, A. S., El-Nokrashy, A. M., Abozeid, A. M., Zaki, V. H., \& Mohamed, R. A. (2021). Dietary supplementation with Bacillus species improves growth, intestinal histomorphology, innate immunity, antioxidative status and expression of growth and appetite-regulating genes of Nile tilapia fingerlings. Aquaculture Research, $n / a(\mathrm{n} / \mathrm{a})$. https://doi.org/10.1111/are.15671

Hauville, M. R., Zambonino-Infante, J. L., Gordon Bell, J., Migaud, H., \& Main, K. L. (2016). Effects of a mix of Bacillus sp. as a potential probiotic for Florida pompano, common snook and red drum larvae performances and digestive enzyme activities. Aquaculture Nutrition, 22(1), 51-60. https://doi.org/10.1111/anu.12226

Keys, A. B. (1928). The Weight-Length Relation in Fishes. Proceedings of the National Academy of Sciences of the United States of America, 14(12), 922-925.

Kong, W., Huang, C., Tang, Y., Zhang, D., Wu, Z., \& Chen, X. (2017). Effect of Bacillus subtilis on Aeromonas hydrophilainduced intestinal mucosal barrier function damage and inflammation in grass carp (Ctenopharyngodonidella). Scientific Reports, 7(1), 1588. https://doi.org/10.1038/s41598-017-01336-9

Kuebutornye, F. K. A., Abarike, E. D., \& Lu, Y. (2019). A review on the application of Bacillus as probiotics in aquaculture. Fish \& $\begin{array}{llll}\text { Shellfish Immunology, } & 87, & 820-828 .\end{array}$ https://doi.org/10.1016/j.fsi.2019.02.010

Kuebutornye, F. K. A., Wang, Z., Lu, Y., Abarike, E. D., et al. (2020). Effects of three host-associated Bacillus species on mucosal immunity and gut health of Nile tilapia, Oreochromis niloticus and its resistance against Aeromonas hydrophila infection. Fish \& Shellfish Immunology, 97, 83-95. https://doi.org/10.1016/j.fsi.2019.12.046

McFarland, J. (1907). The Nephelometer: An Instrument for Estimating the Number of Bacteria in Suspensions used for Calculating the Opsonic Index and for Vaccines. Journal of the American Medical Association, XLIX(14), 1176-1178. https://doi.org/10.1001/jama.1907.25320140022001f

Munir, M. B., Hashim, R., Abdul Manaf, M. S., \& Nor, S. A. M. (2016). Dietary prebiotics and probiotics influence the growth performance, feed utilisation, and body indices of Snakehead (Channa striata) fingerlings. Tropical Life Sciences Research, 27(2), 111-125. https://doi.org/10.21315/tlsr2016.27.2.9 
Myers, D. (2007). Probiotics. Journal of Exotic Pet Medicine, 16(3), 195-197. https://doi.org/10.1053/j.jepm.2007.06.008

Nimrat, S., Suksawat, S., Boonthai, T., \& Vuthiphandchai, V. (2012). Potential Bacillus probiotics enhance bacterial numbers, water quality and growth during early development of white shrimp (Litopenaeus vannamei). Veterinary Microbiology, 159(34), 443-450. https://doi.org/10.1016/j.vetmic.2012.04.029

Opiyo, M. A., Jumbe, J., Ngugi, C. C., \& Charo-Karisa, H. (2019). Different levels of probiotics affect growth, survival and body composition of Nile tilapia (Oreochromis niloticus) cultured in low input ponds. Scientific African, 4, e00103 https://doi.org/10.1016/j.sciaf.2019.e00103

Prabu, E., Rajagopalsamy, C. B. T., Ahilan, B., Jeevagan, I. J. M. A., \& Renuhadevi, M. (2019). Tilapia - An Excellent Candidate Species for World Aquaculture: A Review. Annual Research \& Review in Biology, 31(3), 1-14. https://doi.org/10.9734/arrb/2019/ v31i330052

Rahman, Z., Mahun, A., Ahmad, I., \& Rashid, I. (2019). Influence of Probiotics on the Growth Performance of Sex Reversed Nile Tilapia (Oreochromis niloticus, Linnaeus, 1758) Fry. Journal of Aquaculture Research \& Development, 10(2), 7. https://doi.org/10.4172/2155-9546.1000564

Ridha, M. T., \& Azad, I. S. (2012). Preliminary evaluation of growth performance and immune response of Nile tilapia Oreochromis niloticus supplemented with two putative probiotic bacteria: Probiotic effect on tilapia growth and immunity. Aquaculture Research, 43(6), 843-852. https://doi.org/10.1111/j.1365-2109.2011.02899.x

Samson, J. S., Choresca, C. H., \& Quiazon, K. M. A. (2020). Selection and screening of bacteria from African nightcrawler, Eudrilus eugeniae (Kinberg, 1867) as potential probiotics in aquaculture. World Journal of Microbiology and Biotechnology, 36(1), 16. https://doi.org/10.1007/s11274-019-2793-8

Saravanan, K., Sivaramakrishnan, T., Praveenraj, J., KirubaSankar, R., et al. (2021). Effects of single and multi-strain probiotics on the growth, hemato-immunological, enzymatic activity, gut morphology and disease resistance in Rohu, Labeo rohita. Aquaculture, 540, 736749. https://doi.org/10.1016/ j.aquaculture.2021.736749

Shelby, R. A., Lim, C., Yildirim-Aksoy, M., \& Delaney, M. A. (2006). Effects of probiotic diet supplements on disease resistance and immune response of young Nile tilapia, Oreochromis niloticus. Journal of Applied Aquaculture, 18(2), 23-34. https://doi.org/10.1300/J028v18n02_02
Silva, T. F. A., Petrillo, T. R., Yunis-Aguinaga, J., \& Fernandes, P. (2015). Effects of the probiotic Bacillus amyloliquefaciens on growth performance, hematology and intestinal morphometry in cage-reared Nile tilapia. Latin American Journal of Aquatic Research, 43(5), 963-971. https://doi.org/10.3856/vol43-issue5fulltext-16

Soltan, M. A., Fouad, I. M., \&Elfeky, A. (2016). Growth and feed utilization of Nile tilapia, Oreochromis niloticus fed diets containing probiotic. Global Veterinaria, 17(5), 442-450. https://doi.org/10.5829/idosi.gv.2016.442.450

Sutthi, N., Thaimuangphol, W., Rodmongkoldee, M., Leelapatra, W., \& Panase, P. (2018). Growth performances, survival rate, and biochemical parameters of Nile tilapia (Oreochromis niloticus) reared in water treated with probiotic. Comparative Clinical Pathology. https://doi.org/10.1007/s00580-017-2633-x

Tesch, F. W. (1968). Age and growth. In W. E. Ricker (Ed.), Methods for assessment of fish production in fresh waters (pp. 93123). Blackwell Scientific Publications.

Wang, M., Liu, G., Lu, M., Ke, X., et al. (2017). Effect of Bacillus cereus as a water or feed additive on the gut microbiota and immunological parameters of Nile tilapia. Aquaculture Research, 48(6), 3163-3173. https://doi.org/10.1111/are.13146

Watanabe, W. O., Losordo, T. M., Fitzsimmons, K., \& Hanley, F. (2002). Tilapia Production Systems in the Americas: Technological Advances, Trends, and Challenges. Reviews in Fisheries $\quad$ Science, $\quad$ 10(3-4), 465-498. https://doi.org/10.1080/20026491051758

Won, S., Hamidoghli, A., Choi, W., Park, Y., et al. (2020). Effects of Bacillus subtilis WB60 and Lactococcus lactis on Growth, Immune Responses, Histology and Gene Expression in Nile Tilapia, Oreochromis niloticus. Microorganisms, 8(1), 67. https://doi.org/10.3390/microorganisms8010067

Zhou, X., Tian, Z., Wang, Y., \& Li, W. (2009). Effect of treatment with probiotics as water additive on tilapia (Oreochromis niloticus) growth performance and immune response. Fish Physiology and Biochemistry, 36, 501-509. https://doi.org/10.1007/s10695-0099320-z

Zokaeifar, H., Balcázar, J. L., Saad, C. R., Kamarudin, M. S., et al. (2012). Effects of Bacillus subtilis on the growth performance, digestive enzymes, immune gene expression and disease resistance of white shrimp, Litopenaeus vannamei. Fish \& Shellfish Immunology, 33(4), 683-689. https://doi.org/10.1016/j.fsi.2012.05.027 